Diabetologia 10,449-453 (1974)

(c) by Springer-Verlag 1974

\title{
Function of the Adrenal Cortex in Obese-Hyperglycemic Mice (Gene Symbol ob)
}

\author{
P. Naeser \\ University of Uppsala, Uppsala, Sweden
}

Received: November 23, 1973, and in revised form: June 4, 1974

\begin{abstract}
Summary. The adrenal function of the obese-hyperglycemic mouse has been analysed by measurements of serum corticosteroid levels at different ages and after various types of stimulation. In addition, the corticosteroid binding capacity (CBC) of the serum was evaluated in these animals. The results showed that in all ages investigated the obese hyperglycemic animals had significantly elevated values of serum corticosteroids compared with their lean controls. This difference did not vary with age. Both administration of ACTH and stressful handling further increased the corticosteroid values of the obese animals. In addition, the CBC was significantly elevated in these animals at the ages of 6 and 16 months. Since
\end{abstract}

the serum corticosteroid levels, in contrast to other manifestations of the obese-hyperglycemic syndrome, did not vary with age, it is suggested that the hyperadrenocorticism observed in these animals is not of primary aetiological significance for the development of the syndrome. This does not preclude the possibility that a prolonged elevation of serum corticosteroid levels contributes to the syndrome.

Key words: Obese-hyperglycemic syndrome, obobmice, hyperadrenocorticism, corticosteroids, corticosteroid binding capacity (CBC), adrenal cortex.
Corticosteroid hormones are known to influence both carbohydrate and fat metabolism in mice. Thus, experimentally induced hyperadrenocorticism has been found to cause obesity and pancreatic B-cell hyperplasia, with enlargement of the islets of Langerhans [8]. Mice with the hereditary obese-hyperglycemic syndrome (genotype $o b o b$ ) share many properties with these animals and also have greatly enlarged adrenal glands [12]. In a number of studies attention has therefore been paid to the possible aetiological role of increased adrenal function in the metabolic abnormalities of these animals $[1,9,14,15,21]$. However, the precise role of the adrenal cortex in the development of the obese-hyperglycemic syndrome remains obscure.

In the present study the adrenal function of the obese-hyperglycemic mouse has been further analysed by measurements of serum corticosteroid values at different ages and after various types of stimulation. In addition, the corticosteroid binding capacity of the serum was measured in animals of different ages.

\section{Material and Methods}

\section{Animals}

135 male mice with the obese-hyperglycemic syndrome (gene symbol $o b$ ) and 126 of their male lean litter mates were used at various ages between one and 16 months. The animals belonged to a colony originat ing from The Jackson Laboratory, Bar Harbor, Maine, USA and bred at the Department of Histology, University of Uppsala, Uppsala, Sweden since 1959 as described previously [15].

Blood samples were obtained without anaesthesia from the orbital vein plexus. The blood was collected in dry test tubes and allowed to clot at room tempera- ture. After centrifugation the serum was removed, frozen and stored at $-18^{\circ} \mathrm{C}$ until assayed.

Some animals were given adrenocorticotropic hormone (ACTiI) (Acton, Ferring AB, Malmö, Sweden), $100 \mathrm{mU}$ per animal, intravenously into the tail vein. Blood was collected immediately before and $4,16,20$ and $32 \mathrm{~min}$ after the injection.

To test the reactions of the adrenal cortex in a state of stress, groups of 5 obese and 5 lean mice were placed in a plastic cage with a floor area of $28 \times 19 \mathrm{~cm}$. The cage was shaken vigorously by hand for $15 \mathrm{~min}$. In some animals blood was collected at 16, 20 and 32 min after the beginning of the stressful handling. Otherwise blood was collected immediately before and 20 min later, i.e. 5 min after the shaking ended.

\section{Determination of Serum Corticosteroid Values}

These measurements were made mainly according to DeMoor et al. [4] and the method was adapted to the small amounts of serum available from mice. A standard curve comprising 3 different concentrations $(10$, 20 and $40 \mu \mathrm{g} / 100 \mathrm{ml}$ ) of corticosterone (p.a., E. Merck AG, Darmstadt, W. Germany) dissolved in ethanol and diluted with re-distilled water was run along with each determination of serum corticosterone. Re-distilled water was used as blank. The blood concentration of corticosteroids was expressed as $\mu g$ corticosterone/ $100 \mathrm{ml}$ serum. The error of a single determination varied between $\pm 5-10 \%$ on different days. The lower limit of detection was $1 \mu \mathrm{g}$ corticosterone $/ 100 \mathrm{ml}$.

\section{Determination of the Corticosteroid Binding Capacity $(C B C)$ in Serum}

The competitive protein binding method described by Trapp and West [22] was used for this assay and 
the serum corticosteroid binding capacity (CBC) was expressed as $\mu \mathrm{g}$ corticosterone bound per $100 \mathrm{ml}$ serum. The error of a single determination was $\pm 9 \%$.

\section{Assay of Serum Glucose}

Glucose determinations were performed on duplicate serum samples $(5 \mu \mathrm{l})$ by a glucose oxidase method [11]. A separate blank without glucose oxidase was run for each sample. The error of a single determination was $\pm 3 \%$

\section{Statistical Methods}

The results have been expressed as the mean \pm standard error of the mean (S.E.M.). The significance of the data was tested by Student's t-test [19]. The method error has been assessed from paired measurements by means of the formula $\sqrt{\frac{D^{2}}{2 n}}$, where $D$ is the difference and $\mathbf{n}$ the number of pairs [5]. The influence of age on the corticosteroid levels of the obese and the lean mice was tested by variance analysis [19].

\section{Results}

To test the maximal capacity of the adrenal glands to secrete corticosteroids, ACTH was given intravenously to six month old animals. As shown in Fig. 1, a pronounced effect was recorded with a peak value

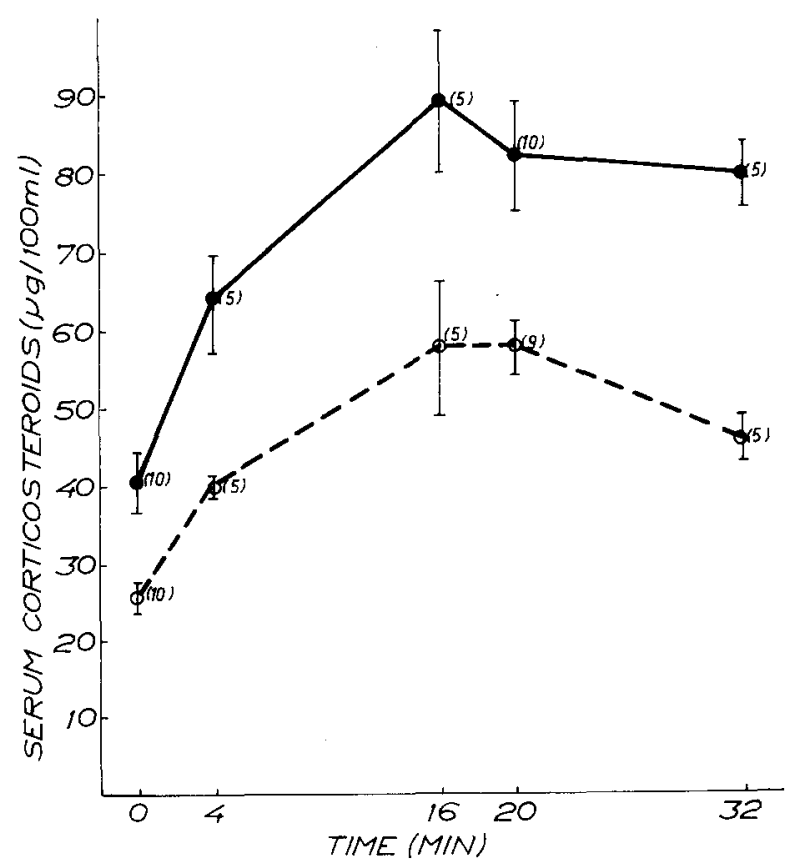

Fig. 1. Serum corticosteroid levels $(\mu \mathrm{g} / 100 \mathrm{ml})$ of 6 month old obese (-) and lean (O-- $\longrightarrow$ ) mice at various times after intravenous injection of ACTH $(100 \mathrm{mU} / \mathrm{ani}$ mal). Numbers of observations within parentheses. Mean values \pm S.E.M. after $16-20 \mathrm{~min}$ in both the obese and the lean mice. The increase was highly significant in both groups ( $P<0.001)$. Within the period of observation $(32 \mathrm{~min})$ no fall to basal levels occurred. Blood sampling alone, as tested in a group of 5 obese and 5 lean mice, 4 months old, also resulted in an increase of the serum corticosteroids. A second sample taken 20 min after the first showed a significant increase both in the obese $(16.5 \pm 5.3 \mu \mathrm{g} / 100 \mathrm{ml}, P<0.05)$ and in the lean mice $(16.5 \pm 0.6 \mu \mathrm{g} / 100 \mathrm{ml}, P<0.001)$. The increases were, however, less than after intravenously administered ACTH or stressful handling (see below) $(P<0.001)$.

The serum corticosteroid values in obese-hyperglycemic mice and their lean litter mates are shown in Table 1. Already at an age of 2 months the obese mice had significantly higher corticosteroid values in serum than their lean controls $(P<0.001)$. This difference between the two groups persisted at all ages investigated. Variance analysis indicated that the serum corticosteroid values were independent of age in both the obese and the lean mice $(P>0.05)$.

As also can be seen in Table 1 the mice responded to stressful handling with increased serum corticosteroid production. Separate control experiments showed that $15 \mathrm{~min}$ handling was sufficient to bring the corticosteroid values to a maximum level, which was maintained for the following $12 \mathrm{~min}$. When obese and lean animals were compared after 15 min stressful handling, it was found that there was significantly higher elevation in those obese mice which belonged to the oldest three groups $(P<0.001)$. Although variance analysis suggested that in neither obese nor lean mice were the corticosteroid values age dependent, there was a significant difference between the values in the two groups of animals at 6, 10 and 12 months of age. At these ages the obese animals had higher values.

A statistical comparison of the results obtained after ACTH injection (Fig. 1) and after stressful handling (Table 1) suggested that the two types of stimuli were on the whole equally effective in raising the serum corticosteroids $(P>0.05)$.

Table 2 shows the serum glucose levels before and after stressful handling in the same animals as in Table 1. The stress was accompanied by a significant increase in the blood glucose level of the two oldest groups of both obese and lean animals. Only those obese mice which were already hyperglycemic during "rest", did. not display any significant further increase $(P>0.05)$.

The CBC levels of both types of mice, aged 1, 6 and 16 months, are shown in Table 3 . In the young age group there was no difference in CBC activity between obese and lean mice $(P>0.05)$. In contrast, both at 6 and 16 months, the obese mice had significantly higher CBC activities than their lean controls $(P<0.001)$. Furthermore, the obese mice displayed a significant difference in CBC activity between 1 and 6 months of age $(P<0.001)$. No corresponding difference was observed in the lean control animals $(P>0.05)$. The lean mice, however, showed a significant decrease in $\mathrm{CBC}$ 
activity between 6 and 16 months of age $(P<0.001)$, a change that was not seen in the obese groups $(P>$ $0.05)$.

\section{Discussion}

The adrenal cortex rapidly responds to stressful stimuli with increased release of corticosteroids. This is mediated via hypothalamic excitation followed by secretion of corticotropin releasing factor and release ues of corticosteroids in blood therefore always involve some degree of uncertainty and it is important to standardize the experimental procedures. Thus, blood sampling should always be performed at the same time of the day since mice also display a circadian rhythm in corticosterone content of the blood $[7,20]$. Housing the animals under similar conditions is of importance as group differences may produce density (crowding) dependent stress reactions [17]. In the present study the blood sample was taken within $30 \mathrm{sec}$ after removal of the animal from the cage and the

Table 1. Serum corticosteroid levels ( $\mu \mathrm{g} / 100 \mathrm{ml}$ ) of obese and lean mice of different ages at rest and after stressful handling. Numbers of observations within parentheses. Mean values \pm S.E.M.

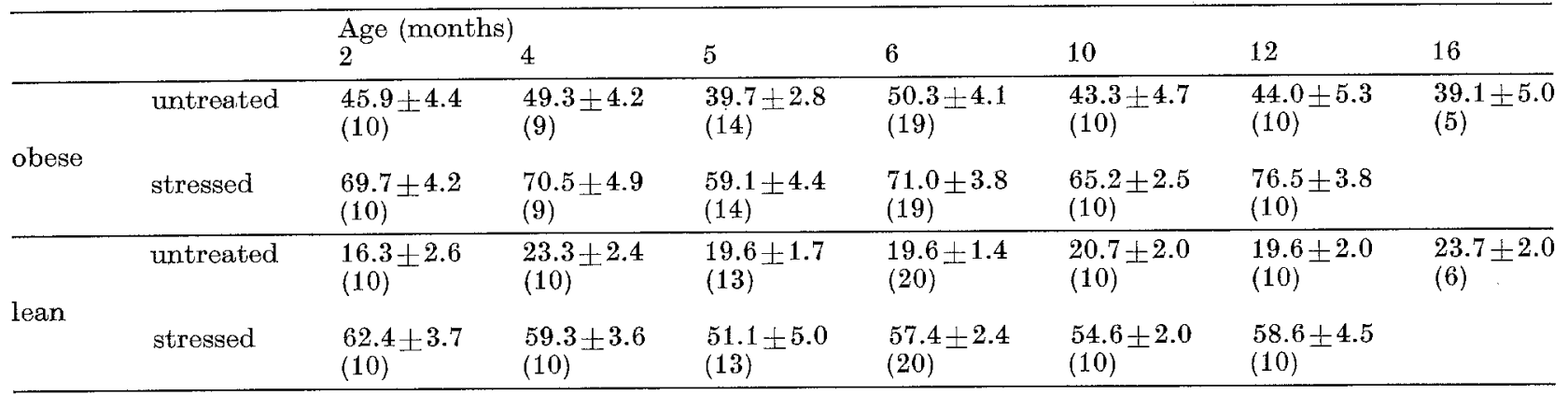

Table 2. Serum glucose levels $(\mathrm{mg} / 100 \mathrm{ml})$ of obese and lean mice of different ages at rest and after stressful handling. Numbers of observations within parentheses. Mean values \pm S.E.M.

\begin{tabular}{|c|c|c|c|c|c|c|c|}
\hline & & $\underset{2}{\text { Age (months) }}$ & 4 & 5 & 6 & 10 & 12 \\
\hline \multirow{2}{*}{ obese } & untreated & $\begin{array}{l}301 \pm 43 \\
(10)\end{array}$ & $\begin{array}{l}399 \pm 29 \\
(9)\end{array}$ & $\begin{array}{l}308 \pm 33 \\
(14)\end{array}$ & $\begin{array}{l}184 \pm 11 \\
(19)\end{array}$ & $\begin{array}{l}121 \pm 9 \\
(10)\end{array}$ & $\begin{array}{l}111 \pm 25 \\
(10)\end{array}$ \\
\hline & stressed & - & $\begin{array}{l}457 \pm 51 \\
(9)\end{array}$ & $\begin{array}{l}329 \pm 32 \\
(14)\end{array}$ & $\begin{array}{l}212 \pm 14 \\
19)\end{array}$ & $\begin{array}{l}155 \pm 6 \\
(10)\end{array}$ & $\begin{array}{l}188 \pm 22 \\
(10)\end{array}$ \\
\hline \multirow{2}{*}{ lean } & untreated & $\begin{array}{l}153 \pm 7 \\
(10)\end{array}$ & $\begin{array}{l}143 \pm 8 \\
(10)\end{array}$ & $\begin{array}{l}\mathbf{1 3 9} \pm 7 \\
(13)\end{array}$ & $\begin{array}{l}143 \pm 6 \\
(20)\end{array}$ & $\begin{array}{l}127 \pm 6 \\
(10)\end{array}$ & $\begin{array}{l}121 \pm 5 \\
(10)\end{array}$ \\
\hline & stressed & - & $\begin{array}{l}192 \pm 12 \\
(10)\end{array}$ & $\begin{array}{l}244 \pm 16 \\
(13)\end{array}$ & $\begin{array}{l}188 \pm 11 \\
(20)\end{array}$ & $\begin{array}{l}156 \pm 6 \\
(10)\end{array}$ & $\begin{array}{l}159 \pm 14 \\
(10)\end{array}$ \\
\hline
\end{tabular}

Table 3. Serum corticosteroid binding capacity (CBC) values $(\mu \mathrm{g} / 100 \mathrm{ml}$ ) of obese and lean mice of different ages. Numbers of observations within parentheses. Mean values \pm S.E.M.

\begin{tabular}{llll}
\hline & Age (months) & & \\
& 1 & 6 & 16 \\
\hline obese & $10.5 \pm 0.7$ & $\mathbf{1 8 . 1 \pm 0 . 7}$ & $\mathbf{1 4 . 5 \pm 2 . 6}$ \\
& $(5)$ & $(5)$ & $(\mathbf{4})$ \\
\hline lean & $11.8 \pm 0.8$ & $12.5 \pm 0.7$ & $8.2 \pm 0.6$ \\
& $(5)$ & $(5)$ & $(11)$ \\
\hline
\end{tabular}

of ACTH from the anterior pituitary [6]. However, it should be emphasized that corticosteroid levels in blood represent a balance between synthesis, release, peripheral binding and degradation and that this $d y$ namic equilibrium is influenced by a great number of widely different factors. Measurements of resting val- sampling was always performed at the same time of the day by a trained person. Although these precautions do not preclude the possibility that changes in the observed serum corticosteroid values had not already occurred before the collection of blood, it seems likely that such effects, if any, were of minor significance. The marked increase of the serum corticosteroids observed when a second sample was taken $20 \mathrm{~min}$ after the first one supports the supposition that before removal from the cage the serum corticosteroid values are more or less normal for these animals. Furthermore, the values for the standard errors obtained for the initial samples were small.

Consistently higher serum corticosteroid levels were recorded in obese-hyperglycemic mice of all age groups as compared with their lean controls. It seems reasonable to interpret this as signifying a true hyperadreno- 
corticism in the obese animals. This notion gains further support from the previous findings of a considerably enlarged adrenal cortex [9] and an increased in vitro secretion of corticosteroids from adrenals of these animals (Naeser, 16). The cause of this increased secretory rate remains, however, to be clarified. The observation that the adrenal glands readily respond to stimulation by ACTH or stressful handling indicates that the adrenocortical cells of the obesehyperglycemic mice are capable of further secretion of corticosteroids in response to both exogenous and endogenous ACTH. This suggests that these cells respond adequately to the pituitary regulation of their functional activity. A more plausible explanation for the hyperadrenocorticism would therefore be a pituitary hypersecretion of ACTH, although there is no direct evidence in favor of this [10].

Corticosteroids may be found in the serum in three different forms, a fraction as unbound steroids, a fraction weakly bound to albumin and a fraction strongly, but reversibly, bound to a specific $\alpha$-globulin, denoted corticosteroid binding globulin [3] or transcortin [18]. The CBC represents the amount of corticosteroids found in the protein fraction after the serum has been overloaded and equilibrated with corticosterone. The corticosteroid levels measured in the serum comprise the total amount of these hormones in the sample, i.e. both the unbound and the protein bound fraction. Thus, an increase in the CBC could theoretically result in elevated corticosteroid levels and mimic hyperadrenocorticism. With this in mind, the low values for CBC found in both lean and obese-hyperglycemic mice do not invalidate the previous conclusion that a hyperadrenocortical state is present in the latter animals. Nevertheless, the increased CBC values in the serum of the 6 and 16 month old obese-hyperglycemic mice is worthy of note since, so far, no spontaneous alteration of CBC activity seems to have been reported in male mice.

In contrast to other manifestations of the obesehyperglycemic syndrome in mice [23] the serum corticosteroid levels of the obese-hyperglycemic mice were not influenced by age. It therefore seems unlikely that the hypersecretion of corticosteroids is of primary, aetiologic significance in the development of the syndrome. Nevertheless, there is evidence to suggest that the longlasting elevation of the serum corticosteroids contributes to the marked insulin resistance of the obese mice, as the serum insulin levels and the hyperglycemia have been shown to decrease significantly after adrenalectomy $[14,15,21]$. Adrenalectomy was, however, found to lack influence on the excessive weight gain of obese mice, indicating that the obesity may also develop in these animals in the presence of a decreased insulin resistance and a deficiency of corticosteroid hormones $[14,15]$. The obese-hyperglycemic syndrome in mice therefore does not seem to represent a genuine "Cushing's syndrome" but rather a multifactorial metabolic disorder of unknown aetiology. The recent demonstration of an insulin-releasing, hypothalamic factor in both rodents and humans [13] and a possible defective satiety centre of obese-hyperglycemic mice [2], suggests that the primary cause of the syndrome could be located in the hypothalamus. In line with this idea, a defective hypothalamic control of ACTH secretion could be an additional feature, which would manifest itself as a hyperadrenocortical state.

Acknowledgements. This work was supported by the Medical Faculty of the University of Uppsala, The Swedish Diabetes Association and The Swedish Medical Research Council. The skilled technical assistance of Miss Astrid Nordin is gratefully acknowledged.

\section{References}

1. Carstensen, H., Hellman, B., Larsson, S. : Biosynthesis of steroids in the adrenals of normal and obese-hyperglycemic mice. Acta Soc. Med. upsalien. 66, 139-151 (1961)

2. Coleman, D.L.: Effects of parabiosis of obese with diabetes and normal mice. Diabetologia 9, 294-298 (1973)

3. Daughaday, W.H.: Binding of corticosteroids by plasma proteins. III. The binding of corticosteroid and related hormones by human plasma and plasma protein fractions as measured by equilibrium dialysis. $J$. clin. Invest. 37, 511-518 (1958)

4. DeMoor, P., Steeno, O., Raskin, M., Hendrikx, A.: Fluorometric determination of free plasma 11-hydroxycorticosteroids in man. Acta endocr. (Kbh.) 33, $297-307$ (1960)

5. Eränkö, O.: Quantitative methods in histology and microscopic histochemistry, p. 23. Basel, New York: S. Karger Publishers 1955

6. Forsham, P.H.: The adrenal cortex. In: Williams, R.H.: Textbook of Endocrinology p. 292. Philadelphia London, Toronto: W. B. Saunders Company, 1968

7. Halberg, F., Albrecht, P.G., Bittner, J.J.: Corticosterone rhythm of mouse adrenal in relation to serum corticosterone and sampling. Amer. J. Physiol. 197, 1083-1085 (1959)

8. Hausberger, F.X.: Islet hypertrophy in obesity, induced by corticosteroids. Fed. Proc. 17, 67 (1958)

9. Hellerström, C., Hellman, B., Larsson, S.: Some aspects of the structure of the adrenals in obese-hyperglycemic mice. Acta path. microbiol. scand. 54, 365$372(1962)$

10. Hellerström, C., Westman, S., Herbai, G., Petersson, B., Westman, J., Borglund, E., Östenson, C.-G.: Pathogenetic aspects of the obese-hyperglycemic syndrome in mice (genotype obob): II. Extrahepatic factors. Diabetologia 6, 284-291 (1970)

11. Hjelm, M., DeVerdier, C.H.: A methodological study of the enzymatic determination of glucose in blood. Scand. J. Clin. Lab. Invest. 15, 415-428 (1963)

12. Marshall, M.B., Andrus, S.B., Mayer, J.: Organ weights in three forms of experimental obesity in the mouse. Amer. J. Physiol. 189, 343-346 (1957)

13. Martin, J.M., Mok, C., Hill, D.E., Crowne, D.: A hypothalamic islet stimulating factor. Excerpta Medica, International Congress Series no. 280, 67 (1973)

14. Naeser, P.: Adrenal function in the obose-hyperglycemic syndrome $(o b o b)$ in mice. Diabetologia $\mathbf{9}, 83$ (1973)

15. Naeser, P.: Effects of adrenalectomy on the obesehyperglycemic syndrome in mice (gene symbol ob). Diabetologia 9, 376-379(1973) 
16. Naeser, P.: In vitro release of corticosteroids from adrenal glands of obese-hyperglycemic mice (gene symbol ob) Acta physiol. scand. In press.

17. Scott, J.P.: Methodology and techniques for the study of animal societies. Ann. N.Y. Acad. Sei. 51, Art. 6, $1001-1005(1950)$

18. Slaunwhite, W.R., Sandberg, A.A.: Transcortin; A corticosteroid-binding protein of plasma. J. clin. Invest. 38, 384-391 (1959)

19. Snedecor, G.W.: Statistical methods, fifth ed. Ames, Iowa: The Iowa State College Press 1956

20. Solem, J.H.: Plasma corticosteroids in mice with special regard to sex difference in adrenocortical responsiveness to exogenous corticotrophin. Scand. J. clin. Lab. Invest. Suppl. 93, $1-36$ (1966)
21. Solomon, J., Mayer, J.: The effect of adrenalectomy on the development of the obese-hyperglycemic syndrome in $a b / o b$ mice. Endocrinology 93, 510-513 (1973)

22. Trapp, G.A., West, C.D.: Determination of corticosteroid-binding proteins by an adsorption method. J. Lab. clin. Med. 73, 861-871 (1969)

23. Westman, S.: Development of the obese-hyperglycemic syndrome in mice. Diabetologia 4, 141 - 149 (1968)

Dr. P. Naeser

Dept. of Histology, Biomedicum

Box 571

S-75123 Uppsala

Schweden 